

\title{
Застосування інгаляційних засобів для зниження частоти загострень хронічного бронхіту
}

\author{
М.М. Кочуєва, ${ }^{1,2}$, І.І. Грек², А.В. Рогожин ${ }^{3}$, Г.І. Кочуєв ${ }^{1}$ \\ ${ }^{1}$ Харківська медична академія післядипломної освіти, Харків, Україна \\ ${ }^{2}$ Харківський національний університет імені В.Н. Каразіна, Харків, Україна \\ ${ }^{3}$ Медичний центр «ОН Клінік», Харків, Україна
}

Анотація. Мета дослідження: оцінити клініко-функціональну ефективність і безпеку розчину для небулайзера ФЛУ-АЦИЛ бронхо в інгаляціях у пацієнтів із хронічним бронхітом для профілактики загострень в період ремісії. Об'єкт і методи дослідження. У дослідження включено 60 пацієнтів віком 25-55 років з хронічним бронхітом в період ремісії, що мали в анамнезі мінімум 1 загострення на рік за останні 3 роки. Пацієнти розділені на групи: 1-ша ( $\mathrm{n}=30)$ - застосовували ФЛУ-АЦИЛ бронхо (1 інгаляція на добу протягом 10 днів), 2-га ( $n=30)$ - амброксол (1 інгаляція 22,5 мг/добу). Обстеження пацієнтів проводили до початку лікування, на 11-й день від початку лікування і у віддалені терміни після завершення терапії - через 30 та 80 днів. Результати. Позитивний результат застосування ФЛУ-АЦИЛ бронхо досягається у 100\% хворих після 10-денного курсу інгаляцій. Позитивний ефект щодо характеру та структури мокротиння у хворих, які застосовують ФЛУ-АЦИЛ бронхо, настає впродовж перших 3 діб лікування, що достовірно швидше, ніж у групі амброксолу (переважно з 3-4-го дня терапії) (р<0,01). У групі ФЛУ-АЦИЛ бронхо 100\% пацієнтів мають достовірний позитивний ефект відносно симптому кашлю протягом 10-денного курсу інгаляцій, при цьому у $40 \%$ з них - вже протягом перших 5 днів терапії. У групі, яка отримувала амброксол, зменшення вираженості симптому кашлю протягом 5 днів відмічали лише у 23,0\% хворих, у 43,0\% - протягом 10 днів інгаляцій, а у 34,0\% значного покращення кашлю після курсу терапії не виявлено (р<0,05). За даними Шкали задишки, кашлю і мокротиння (Breathlessness, cough and sputum scale - BCSS) та Шкали оцінки симптомів хронічного бронхіту (Chronic Bronchitis Symptoms Assessment Scale - CBSAS), у пацієнтів після 10-денного прийому ФЛУ-АЦИЛ бронхо достовірно довше відмічали посттерапевтичний позитивний ефект відносно респіраторних симптомів порівняно з групою амброксолу при достовірно кращих показниках об'єму форсованого видиху за 1-шу секунду, пікової об'ємної швидкості видиху, приросту максимальної об'ємної швидкості на рівні

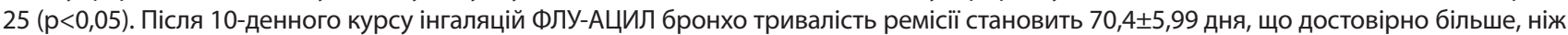
у групі амброксолу $(55,5 \pm 7,62$ дня) (p<0,01). Застосування обох засобів дозволило уникнути загострень хронічного бронхіту у пацієнтів групи спостереження протягом 46-90 днів від початку терапії, тобто як мінімум на 6,5 тиж у 100\% пацієнтів з перевагами на користь ФЛУ-АЦИЛ бронхо. Висновки. Розчин для небулайзеру ФЛУ-АЦИЛ бронхо - засіб з високою клінічною ефективністю у пацієнтів із хронічним бронхітом. Отримані дані дозволяють припустити доцільність застосування 10-денного курсу ФЛУ-АЦИЛ бронхо 1 раз на 3 міс 3 метою цілорічної профілактики загострень хронічного бронхіту (1 раз на 3 міс, 4 рази на рік), що можуть підтвердити результати більш тривалих досліджень із застосуванням ФЛУ-АЦИЛ бронхо протягом року.

Ключові слова: хронічний бронхіт, небулайзер, ацетилцистеїн, ФЛУ-АЦИЛ бронхо, амброксол.

\section{Вступ}

Хронічний бронхіт (ХБ) - дифузне ураження слизової оболонки бронхів, обумовлене тривалим впливом на неї полютантів та/або вірусної та/або бактеріальної інфекції, що супроводжується розвитком запалення, гіперсекрецією слизу і порушенням функції бронхів. Уражаються, як правило, проксимальні бронхи. У них збільшується кількість келихоподібних і зменшується кількість війчастих клітин, з'являються ділянки плоскоклітинної метаплазії епітелію. Зміни мають зазвичай поверхневий характер. За даними Всесвітньої організації охорони здоров'я, бронхіт можна вважати хронічним за наявності кашлю і мокротиння протягом не менше 3 міс на рік упродовж 2 років поспіль. При розвитку захворювання відбувається прогресуюче обмеження повітряного потоку, зазвичай пов'язане з розвитком емфіземи. Загострення бронхіту відзначають в середньому 2-4 рази на рік [1-3].

У виникненні і розвитку ХБ тісно взаємодіють екзогенні та ендогенні фактори. Серед екзогенних факторів істотну роль відіграють полютанти (побутового і професійного характеру), а також неіндеферентний пил, який чинить шкідливу (хімічну та механічну) дію на слизову оболонку бронхів. На 1-ше місце за значенням серед екзогенних факторів слід поставити тютюновий дим. Велике значення мають забруднення повітря і несприятливі кліматичні фактори (переохолодження та перегрівання). Меншу роль серед етіологічних чинників відіграє вірусна (віруси грипу, аденовіруси тощо) і бактеріальна інфекція (мікоплазма, пневмокок, гемофільна паличка, мораксела тощо), але їх значення різко зростає при загостренні ХБ.
Порушення мукоциліарного кліренсу дає можливість бактеріям, які потрапили до бронхіального дерева, розмножуватися, прилипати спочатку до бронхіального слизу, а потім до поверхні слизової оболонки, що підвищує мікробну колонізацію дихальних шляхів. Густий і в'язкий бронхіальний секрет зі зниженим бактерицидним потенціалом стає хорошим поживним середовищем для різних мікроорганізмів $[4,5]$.

3 полегшенням відходження секрету усувається один із важливих чинників зворотної бронхіальної обструкції, а також знижується ймовірність мікробної колонізації дихальних шляхів. Тому при лікуванні хворих із загостренням ХБ необхідно застосовувати препарати, що покращують або полегшують виділення патологічно зміненого бронхіального секрету, запобігають мукостазу і поліпшують мукоциліарний кліренс, а також виявляють антиоксидантну активність. Це досягається значною мірою завдяки застосуванню муколітичних і мукорегуляторних препаратів $[2,3,6]$.

Найкоротшим фізіологічним шляхом потрапляння лікарських засобів у вогнище ураження при захворюваннях органів дихання $\epsilon$ інгаляційний. Серед препаратів із можливістю інгаляційного шляху введення важливе місце займають муколітики. Активними муколітичними засобами $\epsilon$ похідні ацетилцистеїну. Ацетилцистеїн чинить потрійну фармакологічну дію: муколітичну, антиоксидантну, антитоксичну.

Муколітична дія ацетилцистеїну обумовлена здатністю його вільних сульфгідрильних груп розривати дисульфідні зв'язки кислих мукополісахаридів мокротиння, що призводить до деполяризації мукопротеїдів і зменшення в'язкості слизу $[7,9,10]$. Розріджуючи мокротиння, ацетилцистеїн полегшує його виділення; сприяє 
відхаркуванню і зменшує вираженість запальних явищ. Ефективність N-ацетилцистеїну (N-acetylcysteine - NAC) як муколітика при інгаляційному застосуванні підтверджена на великій кількості хворих із порушеною бронхіальної секрецією, з в'язким густим мокротинням; препарат був визнаний як високоефективний та значно полегшив відходження мокротиння [8-11].

Описана здатність ацетилцистеїну блокувати адгезію найбільш частих і активних респіраторних патогенів - Streptococcus pneumoniae, Haemophilus influenzae, Moraxella catarrhalis до епітеліоцитів дихальних шляхів. Доведено, що ацетилцистеїн пригнічує утворення біоплівок грампозитивними і грамнегативними бактеріями і грибами, а також руйнує зрілі біоплівки. Виявлено дозозалежну активність ацетилцистеїну щодо біоплівок Streptococcus pneumoniae та Haemophilus influenzae, які під впливом препарату піддаються частковій дезінтеграції [8-13].

Ацетилцистеїн чинить антиоксидантну дію, обумовлену наявністю нуклеофільної тіолової SH-групи, яка легко віддає водень, нейтралізуючи окисні радикали. Захисний механізм ацетилцистеїну базується на здатності його реактивних сульфгідрильних груп зв'язувати хімічні радикали. Інфекція призводить до посиленого вироблення активних форм кисню, що можуть спричинити загибель клітин та подальшу активацію макрофагів. Ця активація супроводжується виробленням цитокінів, які призводять до запалення та руйнування контактів епітеліальних клітин. Порушення епітеліального бар'єру призводить до підвищеної сприйнятливості до бактеріальної інфекції [14]. Але механізм пневмопротекторного ефекту NAC залежить від шляху застосування. При місцевому застосуванні шляхом інстиляції або через небулайзер концентрація NAC у просвіті дихальних шляхів досягає такої, що забезпечує пряму нейтралізацію часток, наприклад з диму цигарок, або активних форм кисню, що утворюються місцево. Проте при пероральному застосуванні у помірних дозах, наприклад при лікуванні ХБ, накопичення NAC у високих концентраціях у легенях або просвіті дихальних шляхів неможливе [15].

Також ацетилцистеїн робить істотний внесок у глутатіоновий каскад, сприяючи синтезу глутатіону в організмі. Ацетилцистеїн сприяє підвищенню синтезу внутрішньоклітинного глутатіону, який бере участь в окисно-відновних процесах клітин і сприяючи детоксикації шкідливих речовин [8-10].

Одним із добре відомих в Україні засобів патогенетичного призначення мультимодальної дії для швидкої і продуктивної евакуації в'язкого мокротиння у пацієнтів із гострим бронхітом та ХБ $є$ ФЛУ-АЦИЛ бронхо у розчині для небулайзера. Він складається з NAC, що чинить муколітичну дію при безпосередньому контакті зі слизом, та $3 \%$ гіпертонічного розчину $\mathrm{NaCl}$, який забирає воду з внутрішньоклітинного простору в позаклітинний шляхом осмосу та збільшує частку води у бронхіальному секреті, розріджує його і таким чином полегшує його видалення.

Мета дослідження: оцінити клініко-функціональну ефективність і безпеку розчину для небулайзера ФЛУ-АЦИЛ бронхо в інгаляціях у пацієнтів із ХБ для профілактики загострень у період ремісії.

Завдання дослідження включали порівняння терапевтичної ефективності і переносимості двох схем профілактики загострень ХБ: ФЛУ-АЦИЛ бронхо в інгаляціях (300 мг/добу в перерахунку на NAC) та амброксолу (22,5 мг/добу) у формі 1 інгаляції на добу протягом 10-денного курсу.

\section{0б'єкт і методи дослідження}

Учасниками дослідження були хворі на ХБ в період ремісії з симптомом кашлю. У дослідження включено 60 пацієнтів віком 25-55 років з діагнозом «ХБ» в період ремісії, що мали в анамнезі мінімум 1 загострення на рік за останні 3 роки.

Критерії виключення з дослідження: період вагітності, лактація або годування грудним молоком, наявність інфекційного захворювання або стану, що може потребувати прийому антибіотика, онкологічні захворювання, бронхоектатична хвороба, терапія антибіотиками >2 тиж за останній рік не через загострення ХБ, наявність В анамнезі вказівок на реакції гіперчутливості до досліджуваних засобів або їх складових, тяжкі неконтрольовані захворювання серцево-судинної системи, шлунково-кишкового тракту, печінки, нирок, цукровий діабет, алкоголізм, наркоманія.

Усі хворі підписали інформовану згоду на участь у дослідженні.

Пацієнти розділені на групи у співвідношенні 1:1:

- 1-ша (n=30) - застосовували ФЛУ-АЦИЛ бронхо (1 інгаляція на добу протягом 10 днів);

- 2-га (n=30) - амброксол (1 інгаляція 22,5 мг/добу).

Під час дослідження пацієнти не застосовували інші муколітики, відхаркувальні засоби або засоби від кашлю.

Обстеження пацієнтів проводили до початку лікування (візит 1-й), на 11-й день від початку лікування (візит 2-й) і у віддалені терміни після завершення терапії - через 30 (візит 3-й) та 80 днів (візит 4-й).

При 1-му візиті збирали анамнез, з'ясовували особливості перебігу ХБ поза загостреннями і в період загострення, оцінювали поточний стан пацієнта, проводили фізикальне обстеження, пульсоксиметрію, забір крові для проведення загальноклінічного та біохімічного аналізів, клінічне дослідження мокротиння, анкетування (Опитувальник якості життя MOS SF-36, Шкала задишки, кашлю і мокротиння (Breathlessness, cough and sputum scale - BCSS) та Шкала оцінки симптомів хронічного бронхіту (Chronic Bronchitis Symptoms Assessment Scale - CBSAS) $[16,17]$. Два останні опитувальники також давали пацієнтам додому для щоденного моніторингу симптомів. Досліджували функцію зовнішнього дихання (ФЗД) за допомогою спірографа («ХАІ-Медика», Україна) з аналізом основних показників ФЗД.

На наступних візитах відстежували клінічні симптоми загострення, фізикальні дані, проводили клінічний аналіз мокротиння, оцінювали виконання режиму лікування, комплаєнс. Безпеку застосування досліджуваних препаратів оцінювали на підставі реєстрації всіх небажаних проявів під час дослідження, визначали їх зв'язок із досліджуваним засобом.

Профілактику загострень ХБ вважали ефективною (позитивною) при відсутності симптомів і об'єктивних ознак загострення ХБ і наявності ремісії без додаткової антибактеріальної терапії. У разі відмови хворого від лікування (за умови, якщо він виконав хоча 6 одну процедуру дослідження), при неявці його на візити, поганому комплаєнсі, невиконанні режиму лікування клінічний ефект розцінювали як невстановлений. Можливий розвиток загострень відстежували впродовж 90 днів з моменту 1-го візиту.

\section{Результати та їх обговорення}

Залучені у дослідження пацієнти були зіставні за віком, статтю та статусом тютюнокуріння: 70,0\% $(n=42)$ курили в період проведення дослідження, 30,0\% ( $n=18)$ - курили раніше. Обидві групи істотно не відрізнялися за даними анамнезу життя та фізикального обстеження перед початком прийому препаратів. Вони також були зіставні за тривалістю хвороби, кількістю місяців (на рік) виділення мокротиння та кількістю загострень за останній рік. У більшості пацієнтів обох груп при 1-му обстеженні виявлені супутні захворювання: серцево-судинної системи - у 8 (26,7\%) хворих 1-ї та 6 (20,0\%) - 2-ї групи, опорнорухового апарату (остеохондроз різних відділів хребта) - у 14 (46,7\%) хворих 1-ї та 12 (40,0\%) - 2-ї групи, захворювання шлунково-кишкового тракту, печінки, жовчовивідних шляхів - у 6 (20,0\%) хворих 1-ї та 7 (23,3\%) - 2-ї групи. 8,3\% пацієнтів планово отримували лікування з приводу захворювань серцевосудинної системи та 5,0\% - 3 приводу хвороб шлунково-кишкового тракту, інші пацієнти не приймали регулярної терапії стосовно супутньої патології. Середня тривалість ХБ становила $8,9 \pm 3,49$ років в 1 -й групі і 9,27 $\pm 3,06$ років - у 2-й. Середня кількість загострень за попередній рік у хворих 1-ї групи становила $2,9 \pm 1,27$, у 2-й групі - 3,03 11,22. Середня тривалість загострен-

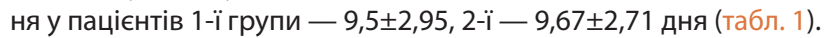

Усі обстежені мали скарги на кашель. У 1-й групі продуктивний кашель відзначали 16 (53,3\%), у 2-й - 18 (60,0\%) пацієнтів. Більшість хворих із продуктивним кашлем $(78,1 \%)$ мали слизисте 
Таблиця 1 Загально-анамнестична характеристика хворих, включених у дослідження

\begin{tabular}{lccc}
\hline \multicolumn{1}{c}{ Показник } & $\begin{array}{c}\text { 1-ша група (n=30) } \\
\text { ФЛУ-АцИЛ бронхо }\end{array}$ & $\begin{array}{c}\text { 2-га група (n=30) } \\
\text { Амброксол }\end{array}$ & p \\
\hline Вік, років & $38,43 \pm 8,55$ & $40,6 \pm 7,63$ & 0,30 \\
\hline Стать, чоловіки/жінки, $\mathrm{n}(\%)$ & $17(56,7) / 13(43,3)$ & $11(36,7) / 19(63,3)$ & 0,16 \\
\hline Гютюнопаління, так/раніше, $\mathrm{n}(\%)$ & $20(66,7) / 10(33,3)$ & $22(73,3) / 8(26,7)$ & 0,60 \\
\hline Анамнез ХБ, років & $8,9 \pm 3,49$ & $9,27 \pm 3,06$ & 0,67 \\
\hline Наявність мокротиння, місяців на рік & $7,2 \pm 2,52$ & $7,63 \pm 2,4$ & 0,54 \\
\hline Кількість загострень на рік & $2,9 \pm 1,27$ & $3,03 \pm 1,22$ & 0,72 \\
\hline Тривалість загострень, днів & $9,5 \pm 2,95$ & $9,67 \pm 2,71$ & 0,83 \\
\hline Супутня патологія, $\mathrm{n}(\%)$ & $20(66,67)$ & $22(73,3)$ & 0,60 \\
\hline Серцево-судинна система, $\mathrm{n}(\%)$ & $8(26,7)$ & $6(20,0)$ & 0,42 \\
\hline Шлунково-кишковий тракт, $\mathrm{n}(\%)$ & $14(46,7)$ & $12(40,0)$ & 0,79 \\
\hline Опорно-рухова система, $\mathrm{n}(\%)$ & $6(20,0)$ & $7(23,3)$ & 0,57 \\
\hline
\end{tabular}

Таблиця 2 Клініко-інструментальна характеристика хворих, включених у дослідження

\begin{tabular}{|c|c|c|c|}
\hline Показник & $\begin{array}{l}\text { 1-ша група }(n=30) \\
\text { ФЛУ-АЦИЛ бронхо }\end{array}$ & $\begin{array}{c}\text { 2-га група }(n=30) \\
\text { Амброксол }\end{array}$ & $\mathbf{p}$ \\
\hline Продуктивний кашель, n (\%) & $16(53,3)$ & $18(60,0)$ & 0,10 \\
\hline $\begin{array}{l}\text { Мокротиння, n (\%): } \\
\text { • слизисте/слизисто-гнійне; } \\
\text { • рідке/помірно в'язке/в'язке }\end{array}$ & $\begin{array}{c}11(36,7) / 5(16,7) \\
6(20,0) / 6(20,0) / 4(13,3)\end{array}$ & $\begin{array}{c}14(46,7) / 4(13,3) \\
7(23,3) / 6(20,0) / 5(16,7)\end{array}$ & $>0,05$ \\
\hline BCSS, бали & $4,27 \pm 1,87$ & $4,7 \pm 2,1$ & 0,39 \\
\hline CBSAS, бали & $15,6 \pm 5,93$ & $17,87 \pm 6,84$ & 0,16 \\
\hline ЖЕЛ & $83,57 \pm 5,6$ & $82,63 \pm 4,85$ & 0,52 \\
\hline ФЖЕЛ & $81,03 \pm 5,33$ & $81,73 \pm 5,23$ & 0,60 \\
\hline $0 \oplus B_{1}$ & $72,4 \pm 5,69$ & $73,13 \pm 5,65$ & 0,61 \\
\hline ОФВ $/$ /ФЖЕЛ & $89,59 \pm 7,57$ & $89,73 \pm 7,83$ & 0,93 \\
\hline ПоШ & $74,07 \pm 5,5$ & $72,9 \pm 5,42$ & 0,39 \\
\hline $\mathrm{MOШ}_{25}$ & $76,57 \pm 6,76$ & $76,6 \pm 5,65$ & 0,98 \\
\hline $\mathrm{MOШ}_{50}$ & $74,1 \pm 6,28$ & $77 \pm 5,17$ & 0,06 \\
\hline $\mathrm{MOШ}_{75}$ & $73,4 \pm 6,12$ & $74,13 \pm 5,49$ & 0,64 \\
\hline
\end{tabular}

Тут і далі: ЖєЛ — життєва ємність легень, ФЖєЛ — форсована життєва ємність легень, $0 Ф B_{1}$ — об'єм форсованого видиху за 1-шу секунду, ПОШ — пікова об'ємна швидкість видиху, МОШ $_{25 / 50 / 75}$ - приріст максимальної об'ємної швидкості на рівні 25/50/75.

мокротиння, 21,9\% - слизисто-гнійне. У більшості випадків за консистенцією мокротиння була помірно в'язким та в'язким. За шкалами оцінки симптомів ХБ BCSS та CBSAS достовірних відмінностей між групами не виявлено. При оцінці результатів спірометричного дослідження встановлено, що показники функції зовнішнього дихання у пацієнтів обох груп були у межах норми та умовно нормальних вікових значень (табл. 2). В усіх хворих відзначено хороший комплаєнс щодо прийому препаратів, всі учасники отримали повний курс профілактики. До завершення дослідження виключення хворих із дослідження не було.

Контрольний візит 1-й відбувся після завершення 10-денного курсу профілактики. Під час цього візиту оцінювали динаміку респіраторних скарг пацієнта, відповідей на опитувальники та переносимість процедур дослідження. Усі пацієнти добре перенесли засоби, що досліджували, не заявляли про небажані явища або побічні реакції і зазначали позитивні ефекти від отриманої терапії. Пацієнти, які на початку мали продуктивний кашель та отримували ФЛУ-АЦИЛ бронхо, відзначали зміну характеру мокротиння та полегшення його відходження вже впродовж перших 3 діб процедур. Деякі пацієнти цієї групи, які початково мали сухий кашель, також відмічали на 1-шу-3-тюдобу $(1,93 \pm 0,69$ дня) появу слизистого мокротиння, яке добре відхаркувалося. При оцінці характеру та інтенсивності кашлю у групі ФЛУ-АЦИЛ бронхо встановлено, що значний позитивний ефект після інгаляцій відзначали всі пацієнти, при цьому 12 з них вже протягом перших 5 днів терапії. На фоні терапії відмічали зменшення вираженості як вранішніх, так і денних симптомів. Пацієнти, які інгаляційно застосовували амброксол, також

відзначали позитивні ефекти процедур. Зокрема, зміна характеру та консистенції мокротиння виявлена в усіх пацієнтів

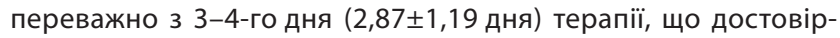
но повільніше, ніж у групі ФЛУ-АЦИЛ бронхо $(p<0,01)$. Також визначена тенденція до зменшення вираженості ранкових та денних симптомів, але з меншим ефектом, ніж у групі ФЛУАЦИЛ бронхо. Лише у 7 пацієнтів відмічено значне зменшення вираженості кашлю протягом 5 днів терапії, ще 13 - протягом 10 днів інгаляцій та у $10-$ не виявлено значного зменшення вираженості кашлю після курсу терапії $(p<0,05)$ (рис. 1, 2).

Через 1 міс після закінчення терапії пацієнти здійснили контрольний візит 2-й, на якому оцінювали динаміку скарг, проводили контрольне спірографічне обстеження та визначали наявність загострень ХБ. При опитуванні пацієнтів та аналізі щоденних анкет встановлено, що респіраторні скарги у вигляді кашлю були наявні майже в усіх пацієнтів, у 4 (6,7\%) хворих загальної когорти характер мокротиння став слизисто-гнійним, у решти пацієнтів із продуктивним кашлем мокротиння було слизовим (55,0\%).

Після аналізу щоденних опитувальників у осіб, які застосовували ФЛУ-АЦИЛ бронхо, виявлено, що зменшення вираженості респіраторних симптомів зберігалося протягом 21,23 44,53 дня після закінчення терапії, що достовірно триваліше, ніж у групі, яка приймала амброксол, $-16,27 \pm 3,08$ дня $(p<0,01)$. Контрольне визначення ФЗД показало, що пацієнти групи ФЛУ-АЦИЛ бронхо мали достовірно кращі показники ОФВ, пОШ та МОШ ${ }_{25}(\mathrm{p}<0,05)$ порівняно з групою амброксолу, хоча результати в обох групах були у межах референтних значень. Динаміка зазначених параметрів на 1-му прийомі та через 1 міс після проведеної терапії представлена на рис. 3 та 4. За 1-й місяць після проведення терапії в обох групах загострень не виявлено.

На останньому контрольному візиті через 80 днів після завершення процедур оцінювали динаміку респіраторних скарг, наявність та тривалість загострень за весь період спостереження та тривалість періоду без загострень з моменту 1-го візиту. Після аналізу анкет та опитування пацієнтів виявилося, що характер

Рисунок 1 Зменшення вираженості симптому кашлю у хворих впродовж курсу профілактики (протягом 5, 10 та після 10 днів)

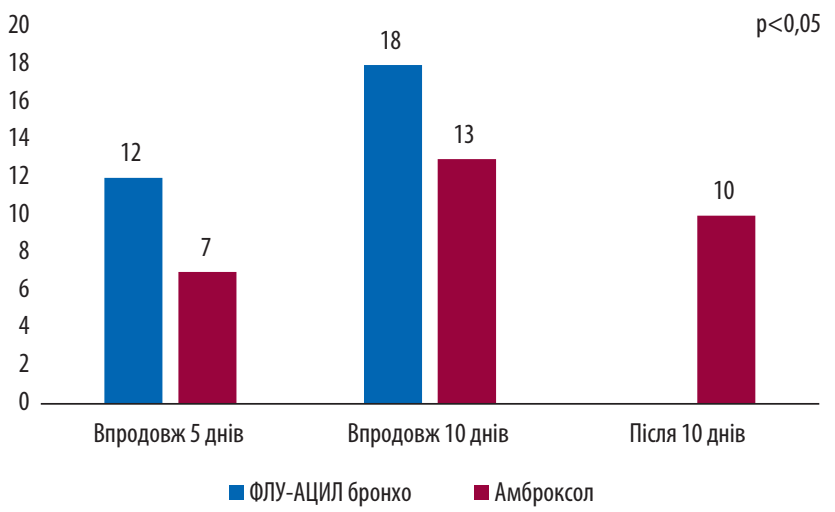

Рисунок 2 Середня кількість днів, необхідних для покращення характеру та структури мокротиння

3

2,5

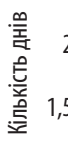

1

0,5

0 $p<0,01$ 
кашлю та мокротиння в них став майже таким, яким був на початку дослідження, однак кількість випадків зі слизисто-гнійним мокротинням все ще була меншою за початкову $-11,7 \%(\mathrm{n}=7)$. У пацієнтів групи ФЛУ-АЦИЛ бронхо відмічали 5 випадків загострень середньою тривалістю 5,2+1,3 дня. Усі загострення відбулися після 61-го дня від 1-го візиту, а середня кількість днів без загострень у групі становила $86,7 \pm 7,81$ дня. У групі амброксолу за період спостереження виявлено 4 загострення середньою

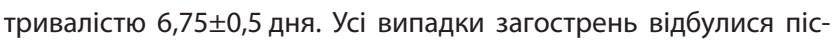
ля 46-го дня спостереження, а середня кількість днів без загострень становила 85,4ะ12,24 дня. За кількістю, тривалістю загострень та періодом без загострень між групами достовірних відмінностей не виявлено. Якщо виділити з кожної групи окремо пацієнтів із загостреннями, то кількість днів без загострень

Рисунок 3 Динаміка параметрів ФЗД у пацієнтів групи ФЛУ-АЦИЛ бронхо на початку дослідження та через 30 днів після курсу профілактики ("p $<0,05)$

120

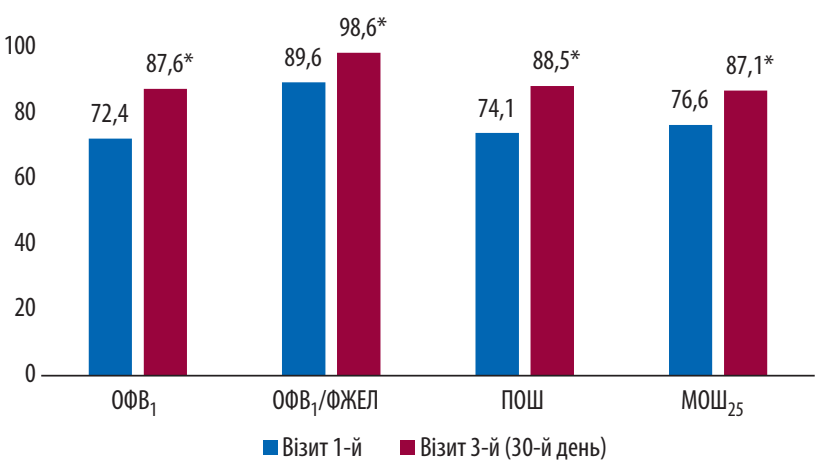

Рисунок 4 Динаміка параметрів ФЗДу пацієнтів групи застосування амброксолу на початку дослідження та через 30 днів після курсу профілактики ("p<0,05)

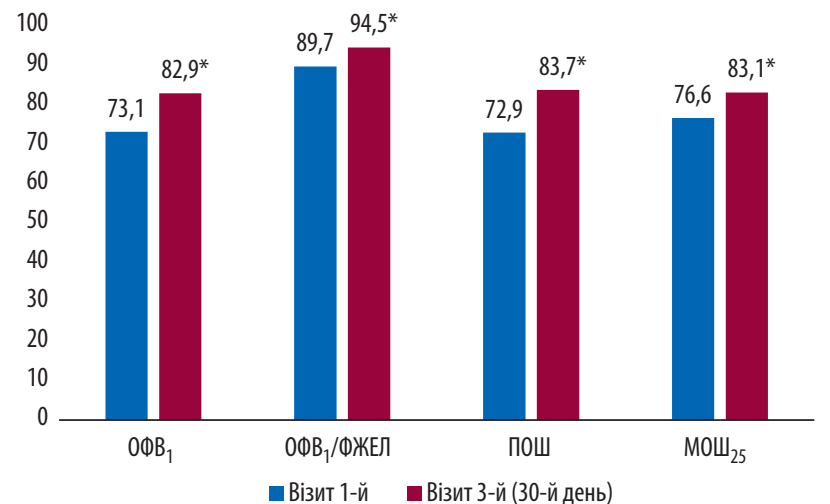

Рисунок 5 Середня тривалість ремісії серед пацієнтів, у яких відмічали загострення ХБ протягом періоду спостереження $(" p<0,01)$

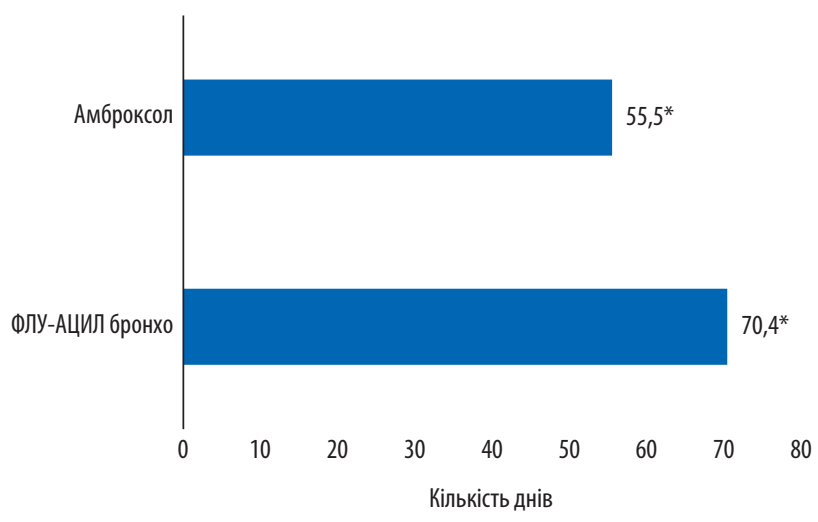

у пацієнтів, що застосовували ФЛУ-АЦИЛ бронхо (70,4 55,99 дня), буде достовірно вищою, ніж у групі амброксолу - 55,5 7,62 дня ( $p<0,01 ;$ рис. 5).

Таким чином, в усіх хворих, включених у дослідження, після завершення курсу профілактики відмічали позитивну клінічну динаміку, однак у групі ФЛУ-АЦИЛ бронхо ефект виявляли достовірно швидше. Це можна пояснити як безпосередньо дією ацетилцистеїну, так і впливом гіпертонічного сольового розчину, який осмотичним шляхом переміщує рідину у позаклітинний простір, збільшує частку води у бронхіальному секреті і сприяє більш швидкому і легкому його відходженню. Більш тривалий ефект та кращі результати спірографічного дослідження після застосування ФЛУ-АЦИЛ бронхо порівняно з амброксолом обумовлені синергізмом муколітичного, протинабрякового та протизапального механізмів дії як ацетилцистеїну, так і гіпертонічного розчину. Завдяки поєднанню цих активностей полегшуються та усуваються симптоми захворювання, зменшується набряк слизової оболонки бронхів, покращуються прохідність і евакуація слизу, реалізуючи більш ефективну санацію бронхіального дерева. Профілактичний ефект ФЛУ-АЦИЛ бронхо відносно розвитку загострень ХБ може бути зумовлений подвійною антимікробною дією препарату. 3 одного боку, ацетилцистеїн має доведені механізми інгібування утворення біоплівок, 3 іншого - гіпертонічний сольовий розчин формує несприятливі умови для утворення біоплівок та сприяє їх механічній евакуації, що знижує вірогідність бактеріальної колонізації бронхів та розвитку загострень ХБ [17-19].

\section{ВИСНОВКИ}

1. Розчин для небулайзера ФЛУ-АЦИЛ бронхо - засіб з високою клінічною ефективністю у пацієнтів із ХБ. Позитивний результат застосування ФЛУ-АЦИЛ бронхо досягається у $100 \%$ хворих після 10-денного курсу інгаляцій (1 інгаляція на добу).

2. Позитивний ефект щодо характеру та структури мокротиння у хворих, які застосовують ФЛУ-АЦИЛ бронхо, настає

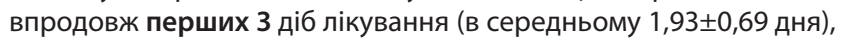
що достовірно швидше, ніж у групі амброксолу (переважно

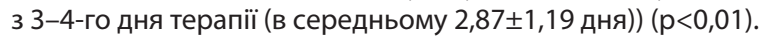

3. У групі ФЛУ-АЦИЛ бронхо у $100 \%$ пацієнтів відмічають достовірний позитивний ефект відносно симптому кашлю протягом 10-денного курсу інгаляцій, при цьому у 40\% з них - вже протягом перших 5 днів терапії. У групі, яка отримувала амброксол, зменшення вираженості симптому кашлю протягом 5 днів відмічали лише у 23,0\% хворих, у 43,0\% - протягом 10 днів інгаляцій, а у $34,0 \%$ значного зменшення вираженості кашлю після курсу терапії не відмічено $(p<0,05)$.

4. За даними опитувальників BCSS та SBSAS, у пацієнтів після 10-денного прийому ФЛУ-АЦИЛ бронхо достовірно довше $(21,23 \pm 4,53$ дня) виявляли посттерапевтичний позитивний ефект відносно респіраторних симптомів порівняно 3 групою амброксолу $(16,27 \pm 3,08$ дня) $(p<0,05)$ при достовірно кращих показниках ОФВ, пОШ, МОШ $25(\mathrm{p}<0,05)$.

5. Після 10-денного курсу інгаляцій ФЛУ-АЦИЛ бронхо трива-

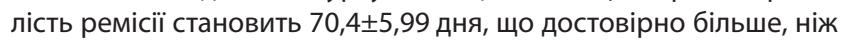
у групі амброксолу $(55,5 \pm 7,62$ дня) $(\mathrm{p}<0,01)$.

6. Застосування обох засобів дозволило уникнути загострень ХБ у пацієнтів групи спостереження $(n=60)$ протягом 46-90 днів від початку терапії, тобто як мінімум на 6,5 тиж у 100\% пацієнтів $з$ перевагами на користь ФЛУ-АЦИЛ бронхо. Отримані дані дозволяють припустити доцільність застосування 10-денного курсу ФЛУ-АЦИЛ бронхо 1 раз на 3 міс з метою цілорічної профілактики загострень ХБ (1 раз на 3 міс, 4 рази на рік), що можуть підтвердити результати більш тривалих досліджень із застосуванням ФЛУ-АЦИЛ бронхо протягом року.

\section{Список використаної літератури/References:}

1. Mejza F., Gnatiuc L., Buist A.S. et al.; BOLD study collaborators (2017) Prevalence and burden of chronic bronchitis symptoms: results from the BOLD study. Eur. Resp. J., 50(5): 1700621. https://doi.org/10.1183/13993003.00621-2017. 
2. Dotan Y., So J.Y., Kim V. (2019) Chronic Bronchitis: Where Are We Now? Chronic obstructive pulmonary diseases (Miami, Fla.), 6(2): 178-192. https://doi.org/10.15326/jcopdf.6.2.2018.0151.

3. Malesker M.A., Callahan-Lyon P., Madison J.M. et al. (2020) Chronic Cough Due to Stable Chronic Bronchitis: CHEST Expert Panel Report. Chest, 158(2): 705-718. https://doi. org/10.1016/j.chest.2020.02.015

4. Chernekhovskaya N.E., Vyrenkova N.Yu., Maltseva I.M. et al. (2018) The state of the ciliated epithelium of the bronchi and mucociliary transport in chronic bronchitis against the background of prolonged smoking. Tuberculosis and lung disease, 96(12): 43-48. https://doi. org/10.21292/2075-1230-2018-96-12-43-48. (In Rus.).

5. Kinkade S., Long N.A. (2016) Acute Bronchitis. Am. Fam. Phys., 94(7): 560-565.

6. Poole P., Sathananthan K., Fortescue R. (2019) Mucolytic agents versus placebo for chronic bronchitis or chronic obstructive pulmonary disease. The Cochrane database of systematic reviews, 5(5): CD001287. https://doi.org/10.1002/14651858.CD001287.pub6.

7. Wei J., Pang C.S., Han J., Yan H. (2019) Effect of Orally Administered N-Acetylcysteine on Chronic Bronchitis: A Meta-analysis. Advances in therapy, 36(12): 3356-3367. https://doi. org/10.1007/s12325-019-01111-4.

8. Beketova G., Soldatova 0. (2018) Acetylcysteine: modern possibilities for use in practice of pediatricians and family doctors. Sovr. Pediatr., 7(95): 69-76. https://doi.org/10.15574/ sp.2018.95.69

9. Šalamon Š., Kramar B., Marolt T.P. et al. (2019) Medical and Dietary Uses of N-Acetylcysteine. Antioxidants (Basel, Switzerland), 8(5): 111. https://doi.org/10.3390/anti0x8050111.

10. Pei Y., Liu H., Yang Y. et al. (2018) Biological Activities and Potential Oral Applications of NAcetylcysteine: Progress and Prospects. Oxidative medicine and cellular longevity, 2835787. https://doi.org/10.1155/2018/2835787.

11. Cazzola M., Calzetta L., Page C. et al. (2015) Influence of N-acetylcysteine on chronic bronchitis or COPD exacerbations: a meta-analysis. European respiratory review: an official journal of the European Respiratory Society, 24(137): 451-461. https://doi. org/10.1183/16000617.00002215.

12. Hendrickson R.G. (2019) What is the most appropriate dose of $\mathrm{N}$-acetylcysteine after massive acetaminophen overdose? Clin. Toxicol. (Philadelphia, Pa.), 57(8): 686-691. https://doi.org /10.1080/15563650.2019.1579914

13. Elbini Dhouib I., Jallouli M., Annabi A. et al. (2016) A minireview on N-acetylcysteine: An old drug with new approaches. Life sciences, 151: 359-363. https://doi.org/10.1016/j. Ifs.2016.03.003.

14. Khomich 0.A., Kochetkov S.N., Bartosch B., Ivanov A.V. (2018) Redox Biology of Respiratory Viral Infections (https://doi:10.3390/v10080392).

15. Moldéus P., Cotgreave I.A., Berggren M. (1986) Lung protection by a thiol-containing antioxidant: N-acetylcysteine. Respiration, 50 Suppl. 1:31-42. https://doi: 10.1159/000195086. PMID: 3809741.

16. Au D.H., Blough D.K., Kirchdoerfer L. et al. (2005) Development of a quantifiable symptom assessment tool for patients with chronic bronchitis: the Chronic Bronchitis Symptoms Assessment Scale. COPD, 2(2): 209-216.

17. Heikkilä P., Korppi M. (2021) Hypertonic saline in bronchiolitis: an updated meta-analysis Archives of disease in childhood, 106(1): 102. https://doi.org/10.1136/archdischild-2020-319048.

18. Huiberts A., Zweijpfenning S., Pennings L.J. et al. (2019) Outcomes of hypertonic saline inhalation as a treatment modality in nontuberculous mycobacterial pulmonary disease. Eur. Resp. J., 54(1): 1802143. https://doi.org/10.1183/13993003.02143-2018.

19. Wark P., McDonald V.M. (2018) Nebulised hypertonic saline for cystic fibrosis. The Cochrane database of systematic reviews, 9(9): CD001506. https://doi.org/10.1002/14651858. CD001506.pub4.

\section{Відомості про авторів:}

Кочуєва Марина Миколаївна - доктор медичних наук, професор, завідувачка кафедри фтизіатрії, пульмонології та сімейної медицини Харківської медичної академії післядипломної освіти, Харків, Україна.

Грек Іван Ігорович — асистент кафедри інфекційних хвороб і клінічної імунології Харківського національного університету імені В.Н. Каразіна, Харків, Україна.

Рогожин Антон Вікторович — кандидат медичних наук, доцент, лікар-пульмонолог, фтизіатр, Медичний центр «ОН Клінік», Харків, Україна.

Кочуєв Геннадій Іванович — кандидат медичних наук, доцент кафедри загальної практики сімейної медицини Харківської медичної академії післядипломної освіти, Харків, Україна.

Адреса для кореспонденції:

Кочуєва Марина Миколаївна

61176, Харків, вул. Амосова, 58
The use of inhalation agents to reduce the frequency of exacerbations of chronic bronchitis

\section{M.M. Kochueva', ${ }^{1,}$ I.I. Greek ${ }^{2}$, A.V. Rogozhin ${ }^{3}$, G.I. Kochuev ${ }^{1}$}

${ }^{1}$ Kharkiv Medical Academy of Postgraduate Education, Kharkiv, Ukraine ${ }^{2}$ V.N. Karazin Kharkiv National University, Kharkiv, Ukraine ${ }^{3}$ «ON Clinic» Medical Center, Kharkiv, Ukraine

Abstract. The purpose of the study: to evaluate the clinical and functional efficacy and safety of the solution for nebulizer FLU-ACYL broncho in inhalation in patients with chronic bronchitis to prevent exacerbations in remission. Object and methods of research. The study included 60 patients aged 25-55 with chronic bronchitis in remission, who had a history of at least 1 exacerbation per year for the last 3 years. Patients were divided into groups: 1 st $(n=30)-$ used FLUACYL broncho (1 inhalation per day for 10 days), 2nd ( $n=30)-$ ambroxol (1 inhalation $22.5 \mathrm{mg}$ per day). Examination of patients was performed before treatment, on the 11 th day from the beginning of treatment and in the long term after the end of therapy - 30 and 80 days. Results. A positive result of the use of FLU-ACYL broncho is achieved in $100 \%$ of patients after a 10-day course of inhalation. A positive effect on the nature and structure of sputum in patients using FLU-ACYL broncho occurs during the first three days of treatment, which is significantly faster than in the group of ambroxol (mostly from 3-4 days of therapy) ( $<<0.01)$. In the group of FLU-ACYL broncho $100 \%$ of patients have a significant positive effect on the symptom of cough during the 10-day course of inhalation, while in $40 \%$ of them - during the first 5 days of therapy. In the group receiving ambroxol, a decrease in the severity of cough symptoms within 5 days was observed in only $23.0 \%$ of patients, in $43.0 \%$ - within 10 days of inhalation, and $34.0 \%$ had no significant improvement in cough after treatment $(p<0.05)$. According to the Breathlessness, Cough and Sputum Scale (BCSS) and the Chronic Bronchitis Symptoms Assessment Scale (CBSAS), in patients after 10 days of FLU-ACYL broncho significantly longer observed post-therapeutic positive effect on respiratory symptoms compared with the group of ambroxol with significantly better indicators of forced expiratory volume for 1 second, peak expiratory volume rate, increase in maximum volume at level $25(p<0.05)$. After a 10-day course of inhalation of FLU-ACYL broncho, the duration of remission is $70.4 \pm 5.99$ days, which is significantly longer than in the group of ambroxol (55.5 \pm 7.62 days) $(p<0.01)$. The use of both drugs avoided exacerbations of chronic bronchitis in patients of the observation group within 46-90 days from the start of therapy, i.e at least 6.5 weeks in $100 \%$ of patients with benefits in favor of FLU-ACYL broncho. Conclusions. FLU-ACYL broncho nebulizer solution is a medical device with high clinical efficacy in patients with chronic bronchitis. The obtained data suggest the feasibility of using a 10-day course of FLU-ACYL broncho 1 time in 3 months for year-round prevention of exacerbations of chronic bronchitis ( 1 time in 3 months, 4 times a year), which may confirm the results of longer studies with FLU-ACYL broncho throughout the year.

Key words: chronic bronchitis, nebulizer, acetylcysteine, FLU-ACYL broncho, ambroxol.

\section{Information about the authors:}

Kochueva Marina M. - Doctor of Medical Sciences, Professor, Head of the Department of Tuberculosis, Pulmonology and Family Medicine, Kharkiv Medical Academy of Postgraduate Education, Kharkiv, Ukraine. Grek Ivan I. - Assistant of the Department of Infectious Diseases and Clinical Immunology, V.N. Karazin Kharkiv National University, Kharkiv, Ukraine.

Rogozhyn Anton V. — Candidate of Medical Sciences, Associate Professor, Pulmonologist, Tuberculosis Specialist, «ON Clinic» Medical Center, Kharkiv, Ukraine.

Kochuev Hennadiy I. - C Candidate of Medical Sciences, Associate Professor of the Department of General Practice - Family Medicine, Kharkiv Medical Academy of Postgraduate Education, Kharkiv, Ukraine.

Address for correspondence:

Marina Kochueva

61176, Kharkiv, Amosov st., 58 